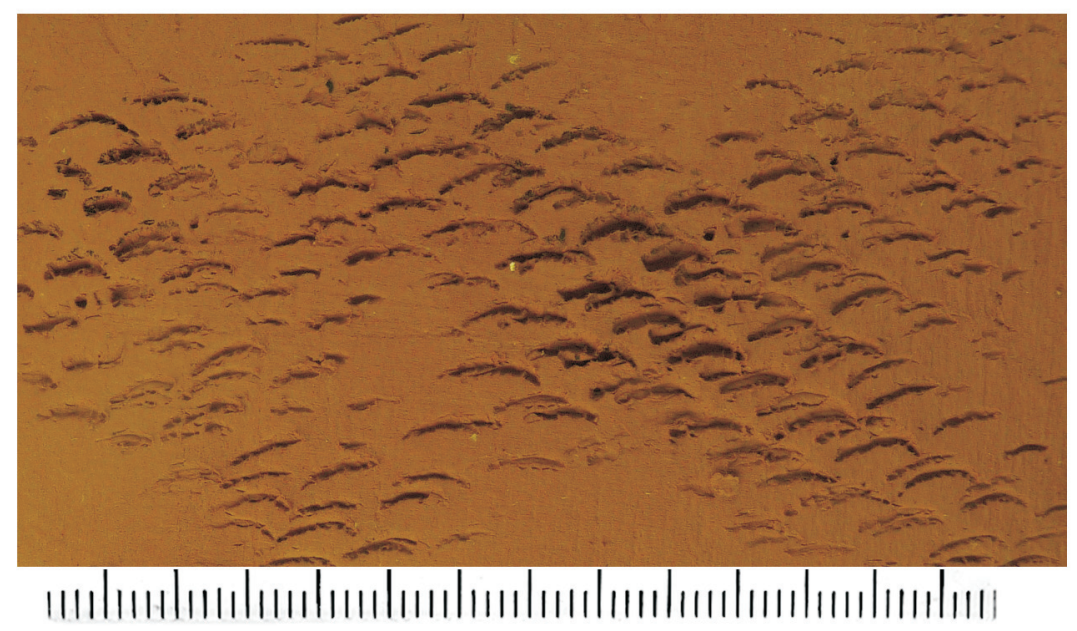

Рисунок 6 - Прокатывание шишкой с обрезанными чешуями, эксперимент.

\title{
THE INVESTIGATION OF METHODS TO APPLY OF «TEXTILE» IMPRINTS ON D'YAKOVO CULTUR CERAMICS
}

(C) 2015

O.A.Lopatina, research fellow, Theory and Method Department, Institute of Archaeology Russian Academy of Sciences, Moscow (Russia)

Abstract. The article contains the results of reconstruction of techniques and instruments, which made «textile» imprints appear on surface of D'yakovo pottery.

The following techniques could cause the appearence of such imprints: 1) constructing in relief concave-forms, 2) paddling, 3) rouletting, 4) punching

Experimental evidence allowed to prove that the «textile» imprints were mainly the result of rouletting.

Special research permitted to establish some srecific signs of roueletting by the example of pottery wholly coverd with impressions of cord («nitochnyje»). The difference between the similar instruments - the roller winded with thread and the plate paddle winded with tread - were revealed.

The technique of rouelling was revealed concerning one more group of pottery - the «speckled» («ryabchatyje») one. The instrument which was used to apply such imprints was also reconstructed. It is the fir cones with partly removed scales. The scales of the cone could be intentionally removed by a human or eaten round by the rodents. Specifity of the traces of the partly removed scales consists in the special outline of the scales, the imprints of the fibre, the traces of rodents' teeth, the imprints of the longitudinal edge of the scales.

The amount of the examined imprints allows to talk about the existence of a certain cultural tradition in the sphere of D'yakovo pottery.

Keywords: D'yakovo cultur; «textile» imprints; experiment; rouletting; reconstruction; ornamenters. 
УДК 902

\title{
К ВОПРОСУ ОБ АБСОЛЮТНОЙ ХРОНОЛОГИИ КЕРАМИКИ ВЕРХНЕВОЛЖСКОЙ КУЛЬТУРЫ: НОВЫЕ ДАННЫЕ ПО МАТЕРИАЛАМ СТОЯНКИ ЗАМОСТЬЕ 2
}

(C) 2015

\author{
Джс. Медоуз, доктор, научный сотрудник \\ Центра Балтийских и Скандинавских исследований музея Шлезвиг-Гольштейн (Германия) \\ B.M.Лозовский, кандидат исторических наук, старший научный сотрудник отдела Палеолита \\ Институт Истории материальной культуры РАН (С-Петербург, Россия), Сергиево-Посадский му- \\ зей заповедник, Сергиев-Посад (Россия) \\ O.B. Лозовская, кандидат исторических наук, научный сотрудник \\ экспериментально-трасологической лаборатории \\ Институт Истории материальной культуры РАН, Сергиево-Посадский музей заповедник, \\ Сергиев-Посад (Россия) \\ C. Чиркова, студентка III курса \\ Департамент Археологии, Университет г.Йорк, Кинг-Манор, Йорк YО1 7ЕР (Англия) \\ О.Крэйг, доктор, профессор \\ Департамент Археологии, Университет г.Йорк, Кинг-Манор, Йорк ҮО1 7 ЕР (Англия) \\ А.Ликин, доктор, научный сотрудник лаборатории БиоАрх \\ Университет Йорка, Б/С блок, Венворт вэй, Хельсингтон, Йорк ҮО10 5DD (Англия) \\ M.Cnатаро, доктор \\ Отделение консервачии и научных исследований, Британский музей (Англия)
}

\begin{abstract}
Аннотация. Стоянка Замостье 2, расположенная на реке Дубна в 100 км к северу от Москвы, представляет собой идеальную возможность понять относительную и абсолютную хронологию керамики ранненеолитической верхневолжской культуры. На данный момент доступно более 100 радиоуглеродных дат, охватывающих всю стратиграфическую последовательность отложений памятника от позднего мезолита к среднему неолиту. Среди 18000 фрагментов представлены все периоды развития верхневолжской культуры, и большинство из них содержат остатки карбонизирнованных органических остатков (нагара), который может быть непосредственно продатирован. Всего на настоящий момент получено 30 радиоуглеродных дат по остаткам нагара на верхневолжской керамике. Тем не менее до сих пор остаются определенные неясности, связанные со временем бытования верхневолжской керамики на стоянке Замостье 2, и большинство из этих вопросов связано с датированием керамики на других памятниках. Более того, абсолютная хронология верхневолжской керамики должна быть подтверждена на основе радиоуглеродных данных по керамике соседних регионов. В данной работе мы обсуждаем альтернативную интерпретацию новых данных, полученных для стоянки Замостье 2.

Ключевые слова: Ранний неолит России; верхневолжская керамика4 нагар; радиоуглеродное датирование; пресноводный резервуарный эффект; стабильные изотопы; EA-IRMS; биомаркеры липидов; GC-MS; GC-cMS; технология керамики; петрография.
\end{abstract}

\section{Introduction}

Pottery first appeared between the Urals and the Baltic at sites dated to between c.7000-5000 cal BC (c.8000$\left.6000 \mathrm{BP}^{1}\right)$. Often these sites are dated by only a few radiocarbon $(14 \mathrm{C})$ samples with large measurement errors $(> \pm 100$ 14C years), whose chronological association with pottery is unclear, leaving considerable room for interpretation and disagreement about the absolute chronologies of different pottery types - and therefore also about the relationships between early pottery types. By critically discussing the $14 \mathrm{C}$ dating of Early Neolithic

1 Following radiocarbon conventions, when discussing archaeological chronologies we convert uncalibrated 14C ages (denoted by BP) to calendar ages (expressed as cal BC), using the IntCal13 calibration data (Reimer et al. 2013). Uncalibrated $14 \mathrm{C}$ ages are used only to discuss the precision and accuracy of $14 \mathrm{C}$ measurements. pottery at Zamostje 2, this paper aims to highlight the various challenges arising in developing absolute chronologies for early pottery types in this vast region.

In principle, Zamostje 2 is the ideal situation to address these challenges, because it has:

- An undisturbed stratigraphic sequence, from the Late Mesolithic to the Middle Neolithic [1, 2, 3].

- Hundreds of potsherds with food-crusts, from Early Neolithic (Upper Volga culture, or UV) and Middle Neolithic (Lyalovskaya culture) pottery, of which 30 have been dated directly $[4,5]$.

- c.70 14C dates from single-entity terrestrial samples (wood, plant fibres and bone) of archaeological material, and c. $2514 \mathrm{C}$ dates on bulk organic sediment (sapropel) from the archaeological layers [6].

Horizontally bedded wood samples, such as fish- 
traps, should be broadly contemporaneous with the other cultural materials in the layers in which they are found, and several examples have been dated at Zamostje 2, including three fish-traps and a paddle from the Early Neolithic layer. There is no particular reason why the appearance of pottery should exactly coincide with these fish-traps, however, both because fish-trap technology already existed in the Mesolithic, and because the preservation, discovery and dating of fish-traps depends on a different set of factors to the recovery of pottery. There is no direct functional relationship between the Early Neolithic pottery and the fish-traps, but their dates should both coincide with the depositional date range of the Early Neolithic layer. Most of the wood samples dated were vertical piles, however, which are not securely stratified, and thus do not help to date the Early Neolithic layer.

The dating of the Early Neolithic layer is also constrained by sapropel 14C dates, whose interpretation is more ambiguous. In areas of the site that were not permanently inundated, sapropel may have been deposited mainly after the artefacts from the same layers. The organic content of sapropel may be derived, in varying proportions, from sources with different $14 \mathrm{C}$ ages - redeposited older peat, and the decomposition of freshly deposited plant remains from littoral vegetation as well as submerged species and other aquatic organisms, which may be depleted in 14C compared to contemporaneous terrestrial species (freshwater reservoir effects; see below), and of intrusive (younger) roots and archaeological wood. In principle, therefore, we might disregard all sapropel dates, but we can use sapropel depositional sequences and dates from horizontallybedded wood to decide which sapropel dates are valid, and to estimate dates of archaeological strata (Fig. 1).

Although two sapropel dates are clearly too young for their stratigraphic positions, the others form acceptable sequences which give compatible estimates of the date of the start of the Early Neolithic in different areas of the site (even if the Neolithic fish-trap dates are omitted from the model). This model, relying only on sapropel and fish-trap dates, places the end of the Late Mesolithic at c.5900 cal BC, or a little earlier, and the start of the Early Neolithic just before $5600 \mathrm{cal}$ BC. The intervening period is filled stratigraphically by the Final Mesolithic layer, for which we only have dates from sapropel and unworked wood within the sapropel. This phase of occupation may have been very brief - which could explain why none of the worked timbers dated (piles or horizontals) apparently falls in this period (Fig. 2). Thus the impression gained from dating both sapropel sequences and timber samples is that pottery was not used at Zamostje 2 during the first third of the 6th millennium cal $\mathrm{BC}$, either because pottery was still unknown in the region, or possibly because this part of site was not occupied for most of this period [3].

\section{Food-crust dating}

Fifteen food-crusts from UV sherds have been dated by the Herzen University laboratory in St Petersburg (laboratory codes $\mathrm{SPb}$-), and $3 \mathrm{UV}$ food-crusts and $3 \mathrm{UV}$ potsherds were dated by the Kiev radiometric laboratory (Ki-). The precision of these results (which have 1-sigma errors of \pm 100 to $\pm 15014 \mathrm{C}$ years) is limited by small sample sizes. Four UV food-crusts have now been dated by the AMS laboratory in Uppsala, Sweden (Ua-), and eight by the Leibniz-Labor, Kiel, Germany (KIA-), with errors of between \pm 30 and $\pm 6314 \mathrm{C}$ years.

The Kiel 14C samples have been analysed by isotopic and biomolecular methods to detect aquatic ingredients, which could cause $14 \mathrm{C}$ reservoir effects. Dietary freshwater reservoir effects (FRE) have been demonstrated at prehistoric cemeteries in central-eastern Europe (e.g., Ostorf, Germany [7]; Ząbie, Poland [8]; Lake Burtnieks, Latvia [9]; Minino, Russia [10]), where human bones appear to be hundreds of years older than organic grave goods. These examples show that rivers and lakes in this region are often very depleted in $14 \mathrm{C}$, and that fish therefore contain carbon with a significantly higher $14 \mathrm{C}$ age than contemporaneous terrestrial ingredients, which should lead to spuriously old $14 \mathrm{C}$ ages for food-crusts made with aquatic ingredients. Hartz et al. [11] have argued that some 14C ages from food-crusts on UV sherds from Ozerki 5, c.150km west of Zamostje 2, and Sakhtysh 2a, c. $150 \mathrm{~km}$ to the east, were subject to FRE, as their $14 \mathrm{C}$ ages were inconsistent with stratigraphic and typological sequences. In the only clear test, however, when a food-crust and a plant fibre used to repair the pot were both dated, their 14C ages were not statistically different, suggesting that most of the carbon in the food-crust was from terrestrial ingredients. One Early Neolithic sherd from Zamostje 2, V002 (Fig. 3 ), has now been dated by the same approach, and the food-crust $14 \mathrm{C}$ age is nearly 300 years greater than the $14 \mathrm{C}$ age of a woody plant fibre used to repair the pot. As microscopic fish scales were seen in the food-crust, the best explanation is that the real date of the pot is given by the plant-fibre $14 \mathrm{C}$ age, and that the food-crust $14 \mathrm{C}$ age is misleadingly old, because of FRE. These results raise two questions: can we retrospectively decide which of the other 30 food-crust dates at Zamostje 2 are subject to FRE, and what is the scale of these 14C age offsets?

FRE offsets will depend on two parameters, the proportion of carbon derived from, and the 14C-depletion in the aquatic ingredients. At inland prehistoric sites in northern Germany, it appears that fish is so isotopically distinct from terrestrial ingredients that food-crusts can be screened using EA-IRMS analysis (Elemental AnalysisIsotope Ratio Mass Spectrometry) to identify those likely to be subject to FRE, but the extreme variability of FRE in local fish (demonstrated in modern samples) makes it almost impossible to estimate the FRE in food-crust $14 \mathrm{C}$ ages [12]. In other situations, the local FRE may be less variable, but isotope values (particularly $\delta 13 \mathrm{C}$ ) may not be sufficiently different between terrestrial and 
aquatic species to distinguish which food-crusts may be subject to FRE. Depending on preservation, lipid biomarker analysis can demonstrate that aquatic species were present, but most of the carbon in food-crusts is not found in the form of soluble lipids. Equally, $\delta 15 \mathrm{~N}$ values in food-crusts may be used to infer whether protein-rich ingredients were predominantly terrestrial or aquatic in origin, but the carbon in food-crusts may be derived mainly from low-protein ingredients, which have little effect on $\delta 15 \mathrm{~N}$ values. Thus it is difficult to quantify the proportion of carbon derived from aquatic ingredients in a dated food-crust.

At Zamostje 2, the 14C ages from V002 are currently the best evidence that local fish was depleted in 14C. EA-IRMS and biomolecular data from the V002 foodcrust are not yet available. Isotope data from the other food-crusts dated in Kiel appear to show a shift towards higher $\delta 15 \mathrm{~N}$ and lower $\delta 13 \mathrm{C}$ values between the Early and Middle Neolithic, which in other contexts would imply a greater emphasis on aquatic species in the Middle Neolithic [13], and which may be reflected in lipid biomarkers from the food-crusts dated in Kiel. Biomolecular analyses of a larger set of Upper Volga pottery food-crusts at Zamostje 2 show that aquatic biomarkers were ubiquitous in the Early Neolithic, however [14], and it thus seems likely that at least some of the other food-crust dates (presumably including the 'oldest') are subject to FRE offsets at least as large as that observed in V002. For most of the dated food-crusts, however, the only indicator of such an offset is the $14 \mathrm{C}$ age itself.

\section{Pre-Neolithic Pottery?}

AMS 14C results from food-crusts on Upper Volga pottery at Zamostje 2 range from $6835 \pm 40 \mathrm{BP}$ (KIA50685 ) to $6480 \pm 30 \mathrm{BP}$ (KIA-50684). V002's food-crust $14 \mathrm{C}$ age, $6816 \pm 49 \mathrm{BP}$ (KIA-50906), is at the upper end of this range, but the plant fibre result, $6545 \pm 48 \mathrm{BP}$ (KIA-50907), is one of the latest AMS dates for UV pottery. Given the larger measurement uncertainties reported, most of the radiometric results could also come from food-crusts whose real $14 \mathrm{C}$ ages fall within the same range as those of the AMS samples (e.g., what appears to be the latest result, Ki-15032, 6300 $\pm 130 \mathrm{BP}$, has a 2-sigma range of 6560-6040 BP). Wooden artefact $14 \mathrm{C}$ results from the Early Neolithic layer range from $6651 \pm 38 \mathrm{BP}$ (structure 156, mean of two 14C ages) to $6505 \pm 30$ BP (fish-trap - sample 86, mean of two 14C ages); a paddle in one of the fish-traps was dated to $6676 \pm 47 \mathrm{BP}$ (CNA-1342) [15]. Thus one reading of the results is that food-crust $14 \mathrm{C}$ ages of c.6700-6500 BP may be valid, and that higher food-crust $14 \mathrm{C}$ ages are due to FRE. According to this reading of the evidence, Upper Volga pottery first appeared at Zamostje 2 around 5600 cal BC, or only shortly before, and the four radiometric $14 \mathrm{C}$ results from food-crusts that appear to significantly pre-date $6700 \mathrm{BP}(\mathrm{SPb}-720,7537 \pm 150 \mathrm{BP}$; SPb-721, 6975 \pm 100 BP; SPb-722, 7105 \pm 150 BP; SPb-
$723,6975 \pm 100 \mathrm{BP}$ ) are misleadingly old, due to FRE. Only SPb-720 would require a greater FRE than that seen in sherd V002 (271 $\pm 6914 \mathrm{C}$ years) to fit this late, short chronology for UV pottery.

An alternative reading of the evidence would emphasise the following observations:

- Even if SPb-720 (7537 $\pm 150 \mathrm{BP})$ was subject to an FRE equal to that observed in V002, after calibration it would still indicate that the sherd almost certainly dates to the 7 th millennium cal $\mathrm{BC}$

- SPb-721 (6975 \pm 100 BP) was from a food-crust containing visible terrestrial plant remains (Viburnum sp. fruits), so it should not be subject to a large FRE

- Given known problems with sapropel 14C ages, the dating of the Final Mesolithic layer is problematic, and the use of sapropel $14 \mathrm{C}$ results to estimate the start of the Early Neolithic may also be misleading; it is notable that the rejected sapropel $14 \mathrm{C}$ results are too recent (Fig. 1)

- Fish-trap 14C results provide only a terminus ante quem for the start of the Early Neolithic, as the oldest Early Neolithic fish-traps may easily have been removed

- The lack of vertical timbers dated to the first third of the 6th millennium may be coincidental, given the presence of timbers dated to later periods that are not apparently represented by ceramics.

Furthermore, there are technological similarities between undecorated sherds from Zamostje 2 and pottery at Serteya and Rakushechny Yar, with even earlier food-crust $14 \mathrm{C}$ ages $[16,17]$. There are, as yet, no petrographic studies on other Upper Volga assemblages for comparison. The 'oldest' food-crust $14 \mathrm{C}$ ages $(\mathrm{SPb}$ 720-723) are from undecorated or sparsely decorated sherds, which may also be expected in later phases; 'younger' 14C ages from undecorated sherds (e.g. $\mathrm{Ki}-15032,6300 \pm 130 \mathrm{BP})$ thus do not invalidate the perception that there was an early 6th millennium phase of undecorated or sparsely decorated pottery.

If there was an older pottery phase at Zamostje 2, it might be visible in the spatial distribution of the dated sherds. The 'oldest' food-crust 14C ages (SPb-721-723; $\mathrm{SPb}-720$ was from a stray find) are from sherds found in a restricted area of the site (quadrats B10-11) and at the same depth (layer 4a), but 'younger' 14C ages were obtained on food-crusts from the same layer and adjoining squares (SPb-725, 6720 $\pm 150 \mathrm{BP}$; SPb-728, $6485 \pm 150 \mathrm{BP}$ ), and four AMS dates for food-crusts from the stratigraphically earlier layer 5 range from $6835 \pm 40$ BP (KIA-50685) to $6650 \pm 30 \mathrm{BP}$ (KIA-50690). If the very early results $(\mathrm{SPb}-721-723)$ from undecorated sherds are not subject to significant FRE offsets, therefore, these sherds may be residual (redeposited, and older than the layer in which they were found), although it must be noted that neither the dated layer 5 sherds nor the Early Neolithic fish-traps were found in the same excavation area as the $\mathrm{SPb}-721-723$ sherds.

Overall, it is easier to fit the $14 \mathrm{C}$ evidence to a scheme in which pottery only appeared at Zamostje 2 in c.5700- 
5600 cal BC, but we cannot dismiss the alternative view, that some undecorated pottery was used in the early 6th millennium. A stronger argument might be made for a pre-Upper Volga phase of pottery at Zamostje 2 if there were technological differences between potentially older sherds and those whose maximum ages (i.e. 14C ages calibrated without correction for FRE) coincide with the fish-trap dates. Current results of petrographic analyses do not show such differences [16].

\section{Other dated sites with Upper Volga pottery}

If, as AMS results imply, the first Upper Volga pottery at Zamostje 2 dates to $5700-5600$ cal BC, or even later, we may ask whether this has implications for the chronology of UV pottery more widely. If the site was actually abandoned for most of the first third of the 6th millennium, as $14 \mathrm{C}$ dates from timber samples might suggest, it is quite plausible that UV pottery appeared earlier elsewhere. If, however, the sapropel 14C dates for the Final Mesolithic are accurate and relevant, they imply that the latest aceramic phase at Zamostje 2 lasted until c.5800-5700 cal BC. Earlier dates for UV pottery at other sites are therefore worth scrutinising closely.

Piezonka [18: Table 10.4] lists 85 14C dates from sites with UV pottery, other than Zamostje 2. As at Zamostje 2 , it is not always clear, even to the excavators, whether bone, charcoal, timber or organic sediment $14 \mathrm{C}$ samples are necessarily contemporaneous with the appearance of pottery. Pottery was directly dated at only three of these sites (at one, Veksa 3, only one food-crust on UV pottery was dated, to 6386 \pm 21 BP (KIA-49797)). Four radiometric $14 \mathrm{C}$ results on UV food-crust samples from Sakhtysh 2a (GIN-10924, 12987-12989; [19, 20]) are comparable to the AMS results at Zamostje 2, but Hartz et al. [11] report several AMS food-crust 14C ages over 7000 BP for UV pottery from Sakhtysh 2a (KIA-39308-39311) and Ozerki 5 (AAR-14542, 14545). Hartz et al. [11] reject the 'oldest' food-crust date at Sakhtysh 2a and both of those from Ozerki 5, on the basis of potential FRE offsets, noting that typologically and stratigraphically the Ozerki 5 sherds belong to a late phase of UV pottery, but they nevertheless accept that three UV sherds at Sakhtysh 2a date to the beginning of the 6th millennium cal $\mathrm{BC}^{2}$. The oldest $14 \mathrm{C}$ age for Upper Volga pottery which cannot be affected by FRE is from a willow fibre used to repair a UV pot at Sakhtysh 2a (KIA-39300, 6847 \pm 31 BP, i.e. 5800-5660 cal BC, $95 \%$ confidence), slightly earlier than the estimated date of the first pottery at Zamostje 2. A food-crust from the same sherd gave an almost identical $14 \mathrm{C}$ age $(6860 \pm 31$ BP, KIA-39301), giving no insight into the potential for FRE in other food-crusts ${ }^{3}$.

\section{Conclusion}

We are unable to assess the validity of the three

2 Although Hartz et al. do not say as much, if these three results (KIA-39308, 39309, 39311) are not misleading, the date of the first UV pot at Sakhtysh 2a must fall before c. 5900 cal BC. older food-crust dates from Sakhtysh 2a that Hartz et al. [11] accepted, but they appear reasonable in the context of $14 \mathrm{C}$ dates from other sites with Upper Volga pottery, on materials such as wood and organic sediment. The accuracy and relevance of all these dates need to be critically discussed to show whether pottery first appeared in central Russia at the start of the 6th millennium, when Zamostje 2 was simply not occupied, or whether pottery was introduced much later than normally assumed. Confirmation that the earliest pottery dates to the beginning of the 6th millennium would lend credence to the handful of 'older' food-crust dates that seem to suggest an earlier phase of pottery at Zamostje, but these results could also be explained by reservoir effects. If they are, and if Zamostje 2 had no pottery before 5700-5600 cal BC, Sakhtyhsh 2a and perhaps other sites already had UV pottery by this date, and from a technological perspective we should focus on these earlier sites to understand the relationship between UV pottery and other, earlier traditions to the south and east.

\section{ACKNOWLEDGMENTS}

This research was partly supported by RFBR project № 13-06-12057 Ofi_M. The KIA - measurements were funded by the Zentrum für Baltische und Skandinavische Archäologie, Stiftung Schleswig-Holsteinische Landesmuseen.

\section{REFERENCES}

1. Lozovski V.M. Zamostje 2. Les derniers chasseurspêcheurs préhistoriques de la Plaine Russe. Guides archéologiques du « Malgré-Tout ». Treignes. Editions de CEDARC, 1996. 96 p.

2. Лозовский В.М., Лозовская О.В. Стратиграфия отложений и культурных слоев стоянки Замостье 2 // Лозовский В.М., Лозовская О.В. (Ред.). Природная среда и модели адаптации озерных поселений в мезолите и неолите лесной зоны Восточной Европы. М-лы Международной науч. конф. Санкт-Петербург, 19-21 мая 2014 г. СПб: ИИМК РАН, 2014. С.46-53.

3. Лозовская О.В., Лозовский В.М. Периоды существования мезолитических и неолитических поселений и проблемы формирования культурных слоев на стоянке Замостье 2 // Древние культуры Восточной Европы: эталонные памятники и опорные комплексы в контексте современных археологических исследований: Замятнинский сборник. Вып. 4. Отв.редактор: Г.А. Хлопачев. СПб.: МАЭ РАН, 2015. С.180-191.

4. Lozovski V.M., Lozovskaya O.V., Zaitceva G.I., Possnert G., Kulkova M. А. Комплекс верхневолжской керамики ранненеолитического слоя стоянки Замостье 2: типологический состав и хронологические рамки (Early Neolithic pottery complex of the Upper Volga culture from site Zamostje 2: typological composition and chronological frames) // Самарский научный вестник. 
2014. № 3(8). c. 122-136.

5. Meadows J., Lozovski V.M., Lozovskaya O.V., Lübke H., Zaitceva G.I., Kulkova M.A. Place of Zamostje 2 site pottery assemblage within the overall chronology of Upper Volga-type pottery // Lozovski V., Lozovskaya O., Vibornov V. (Eds.), Neolithic cultures of Eastern Europe: chronology, paleoecology and cultural traditions. Materials of the International conference dedicated to the 75th anniversary of Victor Petrovich Tretyakov, May 12 - 16, 2015, St. Petersburg. P. 87-91.

6. Lozovski V., Lozovskaya O., Mazurkevich A., Hookk D., Kolosova M. Late Mesolithic-Early Neolithic human adaptation to environmental changes at an ancient lake shore: The multi-layer Zamostje 2 site, Dubna River floodplain, Central Russia//Quaternary International, Volume 324, Human dimensions of palaeoenvironmental change: Geomorphic processes and geoarchaeology. Ed. by M. Bronnikova and A. Panin. 2014. P.146-161.

7. Olsen J., Heinemeier J., Lübke H., Lüth F., Terberger T. Dietary habits and freshwater reservoir effects in bones from a Neolithic NE German cemetery // Radiocarbon. № 52(3). 2010. P. 635

8. Pospieszny Ł. Freshwater reservoir effect and the radiocarbon chronology of the cemetery in Ząbie, Poland // Journal of Archaeological Science. № 53. 2015. P. 264-276.

9. Meadows J., Lübke H., Zagorska I., Bērziņš V., Cerina A., Ozola I. Potential freshwater reservoir effects in a Neolithic shell midden at Riņnukalns, Latvia // Radiocarbon. № 56(2). 2014. P. 823-832.

10. Wood R.E., Higham T.F.G., Buzilhova A., Suvorov A., Heinemeier J., Olsen J., Freshwater radiocarbon reservoir effects at the burial ground of Minino, northwest Russia // Radiocarbon. № 55(1). 2013. P. 163-177.

11. Hartz S, Kostyleva E, Piezonka H, Terberger T, Tsydenova N, Zhilin MG. Hunter-gatherer pottery and charred residue dating: new results on early ceramics in the north Eurasian forest zone // Radiocarbon. № 54(3-4). 2012. P. 1033-1048.

12. Philippsen B., Meadows J. Inland Ertebølle Culture: the importance of aquatic resources and the freshwater reservoir effect in radiocarbon dates from pottery food crusts. 'Human Exploitation of Aquatic Landscapes' special issue (ed. Ricardo Fernandes and John Meadows) // Internet Archaeology. № 37. 2014. http://dx.doi.org/10.11141/ia.37.91.

13. Piezonka H., Meadows J., Hartz S., Nedomolkina N., Ivanishcheva M., Kozorukova N., Terberger T. In preparation. Stone age Pottery chronology in the northeast European forest zone: New AMS and EA-IRMS results on food crusts. To be submitted to Radiocarbon.

14. Craig O., Lozovski V.M., Lozovskaya O.V.,
Chirkova S.S. Organic residue analysis of early Neolithic potsherds and foodcrust samples from Zamostje 2, Russia // Lozovski V., Lozovskaya O., Vibornov V. (Eds.), Neolithic cultures of Eastern Europe: chronology, paleoecology and cultural traditions. Materials of the International conference dedicated to the 75th anniversary of Victor Petrovich Tretyakov, May 12-16, 2015, St. Petersburg. p. 94-96.

15. Lozovski V., Lozovskaya O., Clemente-Conte I., Mazurkevich A., Gassiot-Ballbè E. Wooden fishing structures on the Stone age site Zamostje $2 / /$ Lozovski V., Lozovskaya O., Clemente-Conte I. (Eds), Zamostje 2. Lake Settlement of the Mesolithic and Neolithic Fisherman in Upper Volga Region. St Petersburg, 2013. P. 47-77.

16. Mazurkevich A. N., Dolbunova E. V., Kulkova M. A. Pottery traditions in the Early Neolithic of Eastern Europe. // Российский Археологический Ежегодник. 2013. № 3. С. 27-133.

17. Мазуркевич А.Н., Долбунова Е.В., Кулькова М.А. Ранненеолитические керамические комплексы памятника Замостье 2: технология, типология, хронология // Лозовский В.М., Лозовская О.В., Клементе Конте И. (Ред.), Замостье 2. Озерное поселение древних рыболовов эпохи мезолита-неолита в бассейне Верхней Волги. СПб: ИИМК РАН, 2013. С. 158-181.

18. Piezonka H. Jäger, Fischer, Töpfer. Wildbeutergruppen mit früher Keramik in Nordosteuropa im 6. und 5. Jahrtausend v. Chr. // Archäologie in Eurasien 30. Bonn: Habelt-Verlag. 2015.

19. Zaretskaya N.E., Kostyleva E.L. Radiocarbon Chronology of the Initial Stage of the Upper Volga Early Neolithic Culture (Based on Materials of Sakhtysh 2a Dwelling Site) // Rossiiskaya Arkheologiya. № 1. 2008. P. 5-14.

20. Жилин М.Г., Костылёва Е.Л., Зарецкая Н.Е., Спиридонова Е.А. Природное окружение и история заселения многослойного памятника Сахтыш 2a // Лозовский В.М., Лозовская О.В. (Ред). Природная среда и модели адаптации озерных поселений в мезолите и неолите лесной зоны Восточной Европы. Материалы Международной научной конференции. Санкт-Петербург, 19-21 мая 2014г. СПб.: ИИМК РАН. C. $41-45$

21. Bronk Ramsey C. Bayesian analysis of radiocarbon dates // Radiocarbon. № 51. 2009. P. 337-360. 
Дж. Медоуз, В.М. Лозовский, О.В. Лозовская и др.

\section{FIGURE CAPTIONS}

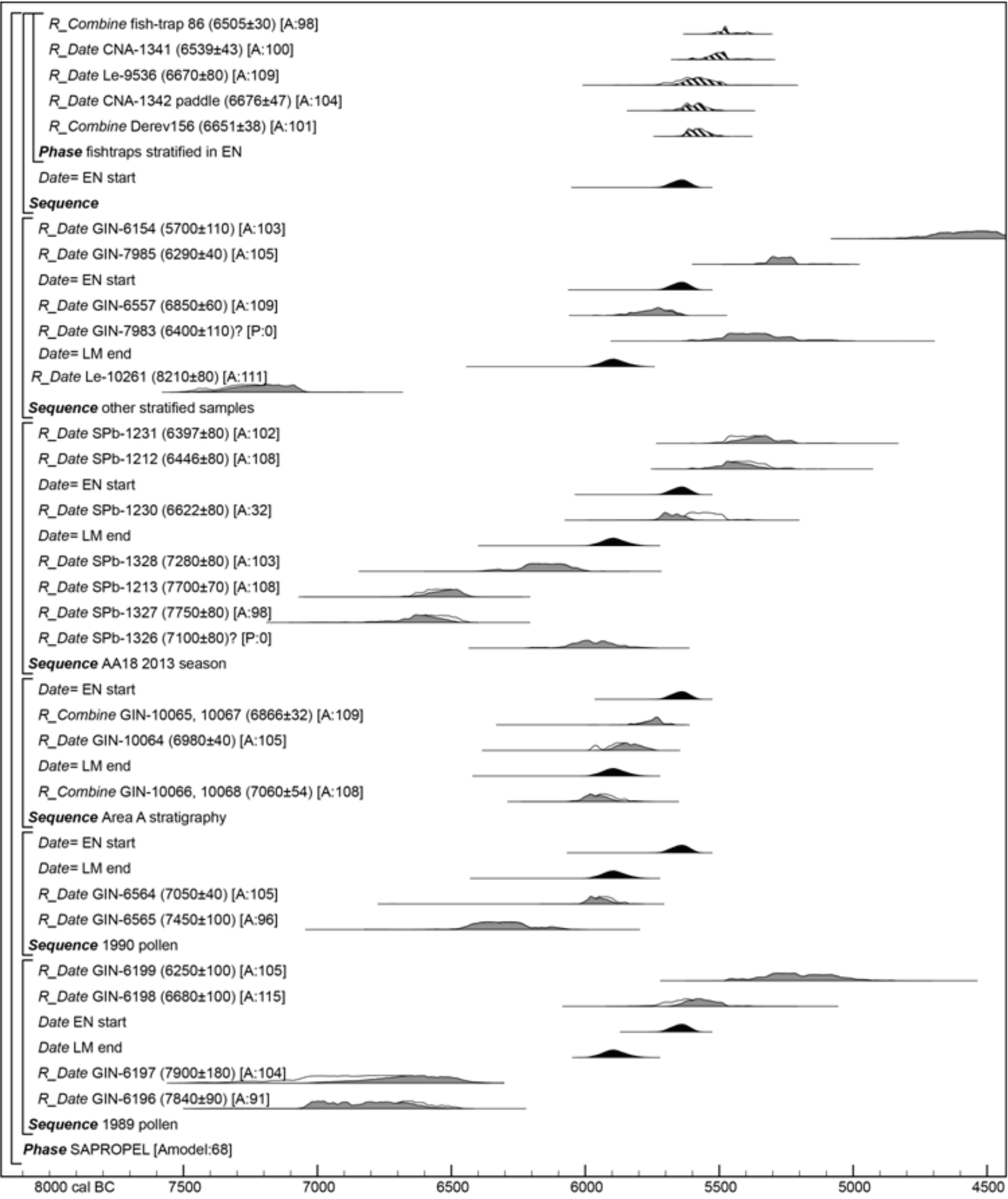

Рисунок 1 - Байесовская хронологическая модель для стоянки Замостье 2, созданная в программе OxСal v.4.3.1 [21], в которой устанавливаются даты для конца позднего мезолита и началу раннего неолита (распределения вероятностей с черной штриховкой датируют конец позднего мезолита и начало раннего неолита), базирующиеся на их позиции в пределах 5 стратиграфических последовательностях образцов сапропеля (распределения вероятностей с серой штриховкой), начало раннего неолита также сопрягается с калиброванными датами для вершей и для образцов древесины с обработкой из слоя раннего неолита (вероятности с косой штриховкой). Два образца по сапропелю (обозначенные знаком “?”), чьи калиброванные даты достаточно молоды для их стратиграфической позиции, не учтены в данной модели. Другие результаты соответствуют стратиграфической последовательности и синхронизация всех 6 последовательностей получена по перекрестному датированию конца позднего мезолита и началу раннего неолита 
Figure 1 - A Bayesian chronological model for Zamostje 2, created in OxCal v.4.3.1 [21], which estimates dates for the end of the Late Mesolithic and the start of the Early Neolithic (black probability distributions Date LM end and Date EN start), based on their positions within 5 stratigraphic sequences of sapropel samples (grey probability distributions); the EN start Date is also constrained by the calibrated dates of fish-traps and other artefactual wood in the Early Neolithic layer (hatched distributions). Two sapropel samples (denoted by “?”) whose calibrated dates are too recent for their stratigraphic positions are omitted from the model. The other results are compatible with the stratigraphic sequences and the synchronisation of these 6 sequences obtained by cross-referencing (Date=) end LM and start EN.

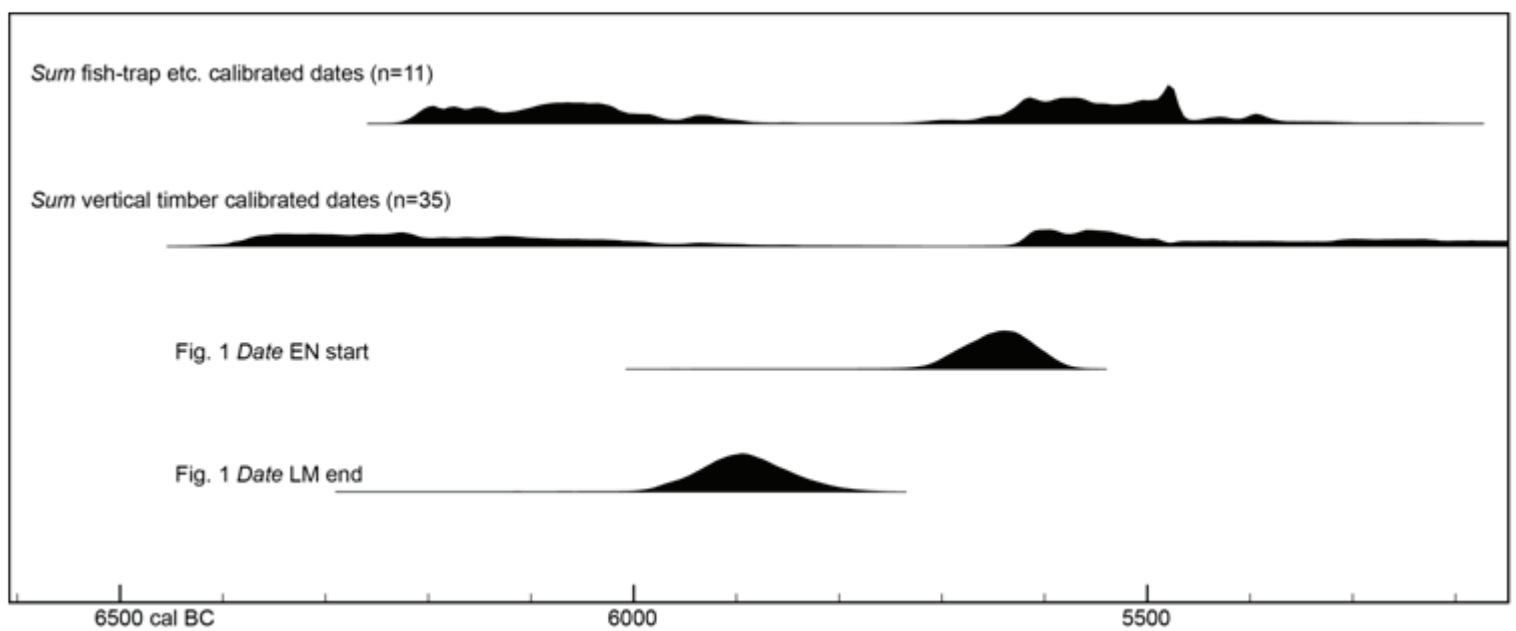

Рисунок 2 - Сравнение установленных дат для конца позднего мезолита и началу раннего неолита (Дата конца позднего мезолита и Дата начала раннего неолита) на стоянке Замостье 2, полученные из байесовской хронологической модели рис. 1, с совокупными распределениями вероятностей (программа OxCal функция Sum) для калиброванных дат по образцам рыболовных конструкций (13 дат для 11 образцов) и по вертикальным кольям (36 дат для 35 образцов), которая показывает, что все датированные колья могут либо датировать конец позднего мезолита либо начало раннего неолита.

Figure 2 - Comparison of the estimated dates for the end of the Late Mesolithic and the start of the Early Neolithic (Date LM end and Date EN start) at Zamostje 2, derived from the Bayesian chronological model shown in Figure 1, with cumulative probability distributions (OxCal function Sum) for the calibrated dates of fishing equipment (13 dates from 11 samples) and timber piles (36 dates from 35 samples), which show that all of the dated timbers could either pre-date the end of the Late Mesolithic or post-date the start of the Early Neolithic.
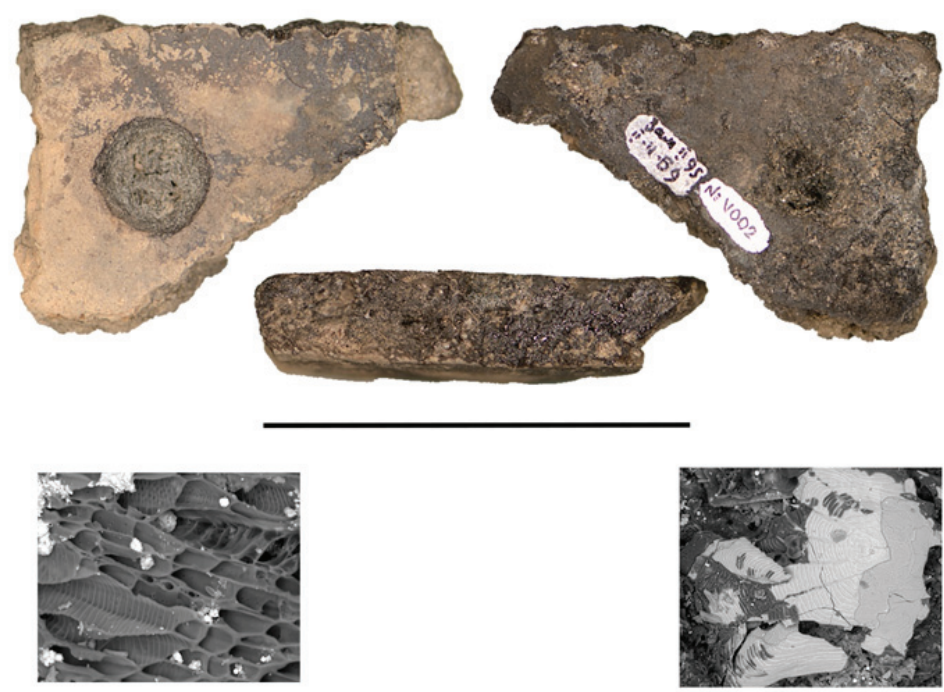

Figure 3: site Zamostje 2. Early Neolithic sherd V002, photographs of (top left) exterior, showing repair hole; (top right) internal surface, showing food-crust and repair hole; (centre) top edge, showing resin used in repair (H. Lübke; scale bar 50mm); Scanning Electron Microscope imaging of (bottom left) woody plant fibre in repair hole (area c.0.20x0.16mm), (bottom right) fish scale embedded in food-crust surface (area c.0.80x0.64mm) (M. Spataro). 
Рис. 3. Стоянка Замостье 2. Образец ранненеолитической керамики V002, фотографии внешней поверхности, показывающая ремонтное отверстие (верхняя левая); фотография, показывающая внутреннюю поверхность, показывающая нагар и ремонтное отверстие (верхняя правая); фотография верхней кромки, показывающая смолу, использованную для ремонта (центр) (фотография H. Lübke, масштаб 50mm); фотографии сделанные с помощью сканирующего электронного микроскопа показывающая древесное или растительное волокно в ремотном отверстии (участок с.0.20x0.16mm) - нижняя левая фотография; чешуя рыбы, включенная в нагар на поверхности фрагмента (участок с.0.80x0.64mm) - нижняя правая фотография (фото M. Spataro).

\section{ABSOLUTE CHRONOLOGY OF UPPER VOLGA-TYPE POTTERY: MORE EVIDENCE FROM ZAMOSTJE 2}

(C) 2015

J. Meadows, Dr Zentrum für Baltische und Skandinavische Archäologie, Stiftung Schleswig-Holsteinische Landesmuseen

Christian-Albrechts-Universität zu Kiel, Kiel (Germany)

V.M.Losovski, Candidate of Historical Sciences, Senior Researcher of the Palaeolithic Institute for the History of Material Culture of the Russian Academy of Sciences; St Petersburg (Russia)

Sergiev-Posad History and Art Museum, Sergiev-Posad(Russia)

O.V.Lozovskaya, Candidate of Historical Sciences, a research fellow experimental laboratory trasological Institute for the History of Material Culture of the Russian Academy of Sciences; St Petersburg (Russia) Sergiev-Posad History and Art Museum, Sergiev-Posad (Russia)

\section{S.Chirkova}

University of York, York (United Kingdom)

o. Craig, doctor

University of York, York (United Kingdom)

A.Lucquin, doctor

University of York, York (United Kingdom)

M. Spataro, $\mathrm{Dr}, \mathrm{PhD}$

The British Museum, London (Great Britain)

Annotation. Zamostje 2, on the Dubna River, c.100km north of Moscow, appears to offer an ideal opportunity to understand the relative and absolute chronology of Upper Volga Early Neolithic pottery. More than 100 radiocarbon (14C) dates are available from a stratigraphic sequence which spans from the Late Mesolithic to the Middle Neolithic. All typological stages are represented among over 18,000 sherds of Early Neolithic pottery, and many of these sherds bear deposits of carbonised food remains (food-crusts), which can be dated directly by 14C; more than 30 food-crusts have been dated directly. Nevertheless, there remains considerable uncertainty about the date range of Upper Volga pottery at Zamostje 2, and many of the issues raised are relevant to dating early pottery at other sites. Moreover, the absolute chronology of Upper Volga pottery must have some bearing on the interpretation of $14 \mathrm{C}$ dates for pottery from adjoining regions. In this paper, we discuss alternative interpretations of the Zamostje 2 evidence.

Keywords: early Neolithic Russia; Upper Volga pottery; food crusts; radiocarbon dating; freshwater reservoir effects; stable isotopes; EA-IRMS; lipid biomarkers; GC-MS; GC-c-MS; ceramic technology; petrography. 